\title{
PENERAPAN DIVERSI DALAM TINGKAT PEMERIKSAAN DI SIDANG PENGADILAN TERHADAP TINDAK PIDANA YANG DILAKUKAN OLEH ANAK (Studi di Pengadilan Negeri Purwokerto) Yulanto Prafifto Utomo \\ (Hakim Pengadilan Negeri Purwoekrto)
}

\begin{abstract}
The negative effects on children in the juvenile justice process, then raised the idea of diversion in the juvenile justice process. This is in line with the concept of restorative justice in the juvenile justice process. Formulation of the problem to be addressed is how the application of the provisions of diversion to criminal assault committed by children in Purwokerto District Court and how the consideration of the judge in determining the Diversion agreement against criminal assault committed by children in P urwokerto District Court.

This type of agreement Diversi Determination No. 3/Pid.Sus Anak/2015/PN P wt is peace without indemnity and surrender to the parents. Consideration judge determines deal of diversion of the offenses committed by children in the District Court of Purwokerto which is between the victim/parent and child/parents have to forgive each other, parents will educate children to be good and not do deprivation of liberty but under surveillance BAPAS, so the child to avoid a negative stigma on his actions.

Keywords: child, criminal, diversion.
\end{abstract}

\begin{abstract}
Abstrak
Efek negatif pada anak pada proses peradilan anak, maka timbul ide diversi dalam proses peradilan anak. Hal ini sejalan dengan adanya konsep restoratif justice dalam proses peradilan anak. Perumusan masalah yang akan dibahas adalah bagaimanakah penerapan ketentuan diversi terhadap perkara tindak pidana yang dilakukan oleh anak di Pengadilan Negeri Purwokerto dan bagaimana pertimbangan hakim dalam menentukan kesepakatan Diversi terhadap perkara tindak pidana yang dilakukan oleh anak di Pengadilan Negeri Purwokerto.

Bentuk kesepakatan Penetapan Diversi Nomor 3/Pid.Sus Anak/2015/PN Pwt adalah perdamaian tanpa ganti kerugian dan penyerahan kepada orang tua. Pertimbangan hakim menentukan kesepakatan diversi terhadap tindak pidana yang dilakukan oleh anak di Pengadilan Negeri Purwokerto yaitu antara korban/orang tua dan anak/orang tua sudah saling memaafkan, orang tua anak akan mendidik anak agar menjadi anak yang baik dan tidak dilakukan perampasan kemerdekaan tetapi dalam pengawasan BAPAS, sehingga anak berhadapan dengan hukum terhindar dari stigma negatif atas perbuatannya tersebut.

Kata Kunci : anak, diversi, pidana.
\end{abstract}

\section{PENDAHULUAN}

Tindak pidana yang dilakukan oleh anak, merupakan bentuk penyimpangan perilaku, namun demikian perilaku anak tersebut janganlah langsung dilihat sama dengan perilaku menyimpang yang dilakukan oleh orang dewasa, oleh karena itu jangan pula seorang anak yang telah melakukan tindak pidana dikatakan sebagai penjahat, sementara kejadiannya adalah proses alami yang tidak boleh tidak setiap manusia harus mengalami kegoncangan selama menjelang kedewasaannya. ${ }^{1}$ Adanya efek negatif pada anak pada proses peradilan anak, maka timbul ide diversi dalam proses peradilan anak. Hal ini sejalan dengan adanya konsep restoratif justice dalam proses peradilan anak. Sistem Peradilan Pidana Anak wajib mengutamakan

Wagiati Soetodjo, 2000, Hukum Pidana Anak, Refika Aditama, Bandung, hal. 2. 
pendekatan Keadilan Restoratif. $^{2}$ Keadilan Restoratif adalah penyelesaian perkara tindak pidana dengan melibatkan pelaku, korban, keluarga pelaku/korban, dan pihak lain yang terkait untuk bersama-sama mencari penyelesaian yang adil dengan menekankan pemulihan kembali pada keadaan semula dan bukan pembalasan. ${ }^{3}$ Pasal 1 angka 7 UndangUndang Republik Indonesia Nomor 11 Tahun 2012 Tentang Sistem Peradilan Anak menyebutkan, Diversi adalah pengalihan penyelesaian perkara Anak dari proses peradilan pidana ke proses di luar peradilan pidana.

Pengadilan Negeri Purwokerto sebagai lembaga peradilan, seringkali menerima, memeriksa dan memutus berkas perkara tindak pidana anak. Berdasarkan data yang ada pada Pengadilan Negeri Purwokerto, tahun 2014 sampai dengan tahun 2015 tercatat menangani tindak pidana anak sebagai berikut : ${ }^{4}$

\begin{tabular}{|c|c|c|c|c|c|c|}
\hline $\begin{array}{l}\mathbf{N} \\
\mathbf{0}\end{array}$ & $\begin{array}{c}\text { Nomo } \\
r \\
\text { Perka } \\
\text { ra }\end{array}$ & $\begin{array}{c}\mathrm{Na} \\
\mathrm{ma} \\
\mathrm{Ana} \\
\mathrm{k}\end{array}$ & $\begin{array}{c}\text { Pasal } \\
\text { Terbuk } \\
\mathbf{t i}\end{array}$ & \begin{tabular}{|c|} 
Tuntut \\
an \\
Penunt \\
ut \\
Umum
\end{tabular} & $\begin{array}{c}\text { Putusan } \\
\text { Hakim } \\
\text { PN }\end{array}$ & $\begin{array}{l}\text { Putu } \\
\text { san } \\
\text { Haki } \\
\text { m PT }\end{array}$ \\
\hline 1 & $\begin{array}{l}\text { 10/Pid } \\
\text {.Sus- } \\
\text { Anak/ } \\
2015 / \\
\text { PN } \\
\text { Pwt }\end{array}$ & $\mathrm{HH}$ & $\begin{array}{c}\text { Pasal } \\
363 \\
\text { Ayat (1) } \\
\text { ke } 3 \\
\text { KUHP }\end{array}$ & $\begin{array}{l}4 \text { bulan } \\
\text { penjara }\end{array}$ & $\begin{array}{l}2 \text { bulan } \\
\text { penjara }\end{array}$ & - \\
\hline 2 & $\begin{array}{l}\text { 9/Pid. } \\
\text { Sus- } \\
\text { Anak/ } \\
2015 / \\
\text { PN }\end{array}$ & $\begin{array}{l}\text { ES } \\
\mathrm{dk}\end{array}$ & $\begin{array}{l}\text { Pasal } \\
363 \\
\text { ayat (1) } \\
\text { ke-3, } \\
\text { ke-4 }\end{array}$ & $\begin{array}{c}\text { ES, } \\
\text { FB, TN } \\
5 \text { bulan } \\
\text { penjara } \\
\text {, JAS } 4\end{array}$ & $\begin{array}{c}\text { ES, FB, } \\
\text { TN } 3 \\
\text { bulan } \\
\text { penjara, } \\
\text { JAS } 2\end{array}$ & \\
\hline
\end{tabular}

Pasal 5 ayat (1) UU RI Nomor 11 Tahun 2012. Pasal 1 angka 6 UU RI Nomor 11 Tahun 2012. http://192.168.88.100:81/cts3 pn/index/index.php diakses pada tanggal 23 November 2015, pukul 16.18 WIB.

\begin{tabular}{|c|c|c|c|c|c|c|}
\hline & Pwt & & $\begin{array}{l}\text { dan ke- } \\
5 \mathrm{KUHP}\end{array}$ & \begin{tabular}{|c|} 
bulan \\
penjara
\end{tabular} & $\begin{array}{c}\text { bulan } 10 \\
\text { hari } \\
\text { penjara }\end{array}$ & \\
\hline 3 & $\begin{array}{c}\text { 8/Pid. } \\
\text { Sus- } \\
\text { Anak/ } \\
\text { 2015/ } \\
\text { PN } \\
\text { Pwt }\end{array}$ & DI & $\begin{array}{c}\text { Pasal } \\
363 \\
\text { ayat (1) } \\
\text { ke-3, } 4 \\
\text { KUHP }\end{array}$ & $\begin{array}{l}2 \text { bulan } \\
\text { penjara }\end{array}$ & $\begin{array}{l}1 \text { bulan } \\
10 \text { hari }\end{array}$ & - \\
\hline 4 & $\begin{array}{c}\text { 7/Pid. } \\
\text { Sus- } \\
\text { Anak/ } \\
\text { 2015/ } \\
\text { PN } \\
\text { Pwt }\end{array}$ & $\begin{array}{l}\text { NA } \\
M\end{array}$ & $\begin{array}{c}\text { Pasal } \\
363 \\
\text { ayat (1) } \\
\text { ke3, } 5 \\
\text { KUHP }\end{array}$ & $\begin{array}{l}4 \text { bulan } \\
\text { penjara }\end{array}$ & $\begin{array}{l}2 \text { bulan } \\
\text { penjara }\end{array}$ & - \\
\hline 5 & $\begin{array}{c}\text { 6/Pid. } \\
\text { Sus- } \\
\text { Anak/ } \\
2015 / \\
\text { PN } \\
\text { Pwt }\end{array}$ & $\begin{array}{c}\mathrm{NH} \\
\mathrm{P}\end{array}$ & $\begin{array}{c}\text { Pasal } \\
363 \\
\text { ayat (1) } \\
\text { ke } 3 \mathrm{e} \\
\text { dan ke } \\
5 \mathrm{e} \\
\text { KUHP }\end{array}$ & $\begin{array}{l}2 \text { bulan } \\
\text { penjara }\end{array}$ & $\begin{array}{l}1 \text { bulan } \\
\text { penjara }\end{array}$ & - \\
\hline 6 & $\begin{array}{c}\text { 5/Pid. } \\
\text { Sus- } \\
\text { Anak/ } \\
\text { 2015/ } \\
\text { PN } \\
\text { Pwt }\end{array}$ & AM & $\begin{array}{c}\text { Pasal } \\
372 \\
\text { KUHP }\end{array}$ & $\begin{array}{c}10 \\
\text { bulan } \\
\text { penjara }\end{array}$ & $\begin{array}{l}7 \text { bulan } \\
\text { penjara }\end{array}$ & - \\
\hline 7 & $\begin{array}{c}\text { 4/Pid. } \\
\text { Sus- } \\
\text { Anak/ } \\
\text { 2015/ } \\
\text { PN } \\
\text { Pwt }\end{array}$ & $\begin{array}{l}\text { BA } \\
P \\
\mathrm{dk}\end{array}$ & $\begin{array}{c}\text { Pasal } \\
363 \\
\text { Ayat (1) } \\
\text { ke } 4\end{array}$ & $\begin{array}{l}2 \text { bulan } \\
\text { penjara }\end{array}$ & $\begin{array}{l}1 \text { bulan } \\
15 \text { hari } \\
\text { penjara }\end{array}$ & - \\
\hline 8 & $\begin{array}{c}\text { 3/Pid. } \\
\text { Sus- } \\
\text { Anak/ } \\
\text { 2015/ } \\
\text { PN } \\
\text { Pwt }\end{array}$ & BS & $\begin{array}{l}480 \mathrm{ke}- \\
1 \mathrm{KUHP}\end{array}$ & Dive & ersi Berha & \\
\hline 9 & $\begin{array}{l}\text { 2/Pid. } \\
\text { Sus- } \\
\text { Anak/ } \\
2015 / \\
\text { PN } \\
\text { Pwt }\end{array}$ & AS & $\begin{array}{l}\text { Pasal } \\
365 \\
\text { ayat ( } 2 \\
\text { ) ke-1, } \\
\text { ke- 2, } \\
\text { ke-3 }\end{array}$ & $\begin{array}{c}10 \\
\text { bulan } \\
\text { penjara }\end{array}$ & $\begin{array}{l}6 \text { bulan } \\
\text { penjara }\end{array}$ & - \\
\hline
\end{tabular}




\begin{tabular}{|c|c|c|c|c|c|c|}
\hline & & & KUHP & & & \\
\hline $\begin{array}{l}1 \\
0\end{array}$ & $\begin{array}{l}\text { 1/Pid. } \\
\text { Sus- } \\
\text { Anak/ } \\
2015 / \\
\text { PN } \\
\text { Pwt }\end{array}$ & $\begin{array}{c}\mathrm{RY} \\
\mathrm{T}\end{array}$ & $\begin{array}{c}\text { Pasal } \\
363 \\
\text { Ayat (1) } \\
\text { ke-3 } \\
\text { dan ke- } \\
5 \text { KUHP }\end{array}$ & $\begin{array}{l}1 \text { tahun } \\
\text { penjara }\end{array}$ & 6 bulan & - \\
\hline $\begin{array}{l}1 \\
1\end{array}$ & $\begin{array}{l}\text { 4/Pid. } \\
\text { Sus- } \\
\text { Anak/ } \\
2014 / \\
\text { PN } \\
\text { Pwt }\end{array}$ & DK & $\begin{array}{c}\text { Pasal } \\
363 \\
\text { Ayat (1) } \\
\text { ke-3 } \\
\text { dan ke- } \\
5 \mathrm{KUHP}\end{array}$ & $\begin{array}{l}1 \text { tahun } \\
2 \text { bulan } \\
\text { penjara }\end{array}$ & 4 bulan & $\begin{array}{l}\text { Meng } \\
\text { uatka } \\
\text { n } \\
\text { Putus } \\
\text { an } \\
\text { PN }\end{array}$ \\
\hline $\begin{array}{l}1 \\
2\end{array}$ & $\begin{array}{l}\text { 3/Pid. } \\
\text { Sus- } \\
\text { Anak/ } \\
2014 / \\
\text { PN } \\
\text { Pwt }\end{array}$ & $A R$ & $\begin{array}{c}\text { Pasal } \\
81 \text { ayat } \\
(2) \\
\text { Undang } \\
- \\
\text { Undang } \\
\text { Nomor } \\
23 \\
\text { Tahun } \\
2002 \\
\text { tentang } \\
\text { Perlind } \\
\text { ungan } \\
\text { Anak }\end{array}$ & $\begin{array}{c}2 \text { tahun } \\
\text { penjara } \\
\text { dan } \\
\text { denda } \\
\text { sebesa } \\
\text { r Rp. } \\
60 \text { juta } \\
\text { sub 3 } \\
\text { bulan } \\
\text { latihan } \\
\text { kerja }\end{array}$ & $\begin{array}{c}1 \text { tahun } \\
6 \text { bulan } \\
\text { penjara } \\
\text { dan } \\
\text { denda } \\
\text { sebesar } \\
\text { Rp. } 60 \\
\text { juta sub } \\
1 \text { bulan } \\
\text { pelatihan } \\
\text { kerja }\end{array}$ & \\
\hline $\begin{array}{l}1 \\
3\end{array}$ & $\begin{array}{l}\text { 2/Pid. } \\
\text { Sus- } \\
\text { Anak/ } \\
2014 / \\
\text { PN } \\
\text { Pwt }\end{array}$ & $\begin{array}{c}\text { RA } \\
\mathrm{S}\end{array}$ & $\begin{array}{c}\text { Pasal } \\
363 \\
\text { ayat }(1) \\
\text { ke } 4 \\
\text { KUHP }\end{array}$ & $\begin{array}{l}4 \text { bulan } \\
\text { penjara }\end{array}$ & $\begin{array}{c}\text { Pembina } \\
\text { an di } \\
\text { Lembag } \\
\text { a PSMP } \\
\text { Antasen } \\
\text { a } \\
\text { Magelan } \\
\text { g selama } \\
6 \text { (enam) } \\
\text { bulan }\end{array}$ & $\begin{array}{l} \\
\text { Meng } \\
\text { uatka } \\
\text { n } \\
\text { Putus } \\
\text { an } \\
\text { PN }\end{array}$ \\
\hline $\begin{array}{l}1 \\
4\end{array}$ & $\begin{array}{l}\text { 1/Pid. } \\
\text { Sus- } \\
\text { Anak/ } \\
2014 / \\
\text { PN } \\
\text { Pwt }\end{array}$ & WA & $\begin{array}{c}\text { Pasal } \\
363 \\
\text { ayat (1) } \\
\text { ke-4 } \\
\text { KUHP }\end{array}$ & $\begin{array}{l}4 \text { bulan } \\
\text { penjara }\end{array}$ & $\begin{array}{c}\text { Pembina } \\
\text { an di } \\
\text { Lembag } \\
\text { a PSMP } \\
\text { Antasen } \\
\text { a } \\
\text { Magelan } \\
\text { g selama } \\
6 \text { (enam) } \\
\text { bulan }\end{array}$ & $\begin{array}{l} \\
\text { Meng } \\
\text { uatka } \\
\text { n } \\
\text { Putus } \\
\text { an } \\
\text { PN }\end{array}$ \\
\hline
\end{tabular}

Berdasarkan data penanganan perkara tindak pidana yang dilakukan oleh anak dari Pengadilan Negeri Purwokerto tersebut, diperoleh gambaran ada 1 (satu) perkara anak yang dilakukan diversi yaitu perkara Nomor 5/Pid.Sus-Anak/2015/PN Pwt. Berdasarkan uraian latar belakang di atas, Penulis tertarik untuk meneliti penerapan diversi terhadap perkara pidana anak di Pengadilan Negeri Purwokerto.

\section{PERUMUSAN MASALAH}

Berdasarkan latar belakang masalah di atas, dirumuskan masalah tersebut sebagai berikut: pertama, bagaimanakah penerapan ketentuan diversi terhadap perkara tindak pidana yang dilakukan oleh anak di Pengadilan Negeri Purwokerto; kedua, bagaimana pertimbangan hakim dalam menentukan kesepakatan Diversi terhadap perkara tindak pidana yang dilakukan oleh anak di Pengadilan Negeri Purwokerto.

\section{METODE PENELITIAN}

Penelitian ini adalah penelitian kualitatif dengan pendekatan yuridis sosiologis. ${ }^{5}$ Penelitian ini menggunakan tipe penelitian lapangan (field research). Spesifikasi yang digunakan dalam penelitian ini adalah spesifikasi penelitian deskriptif. ${ }^{6}$ Lokasi penelitian ini dilakukan di Pengadilan Negeri Purwokerto. Data yang digunakan dalam penelitian ini berupa: a. Data Primer, yaitu data yang bersumber dari pendapat langsung para narasumber dalam hal ini Hakim Pengadilan Negeri Purwokerto,

5 Ronny Hanitijo Soemitro, 1998, Metodologi Penelitian Hukum dan J urimetri, Ghalia Indonesia, Jakarta, hal. 35.

$6 \quad$ Ibid, hal. 16. 
Petugas Bapas, pelaku anak dan korban. b. Data Sekunder, adalah data yang sudah tersusun dalam bentuk dokumen-dokumen. Sumber data sekunder antara lain mencakup bahan primer berupa ketentuan perundangan dan peraturan lainnya yang berkaitan dengan perkara anak serta putusan-putusan pengadilan tentang perkara anak. Selain itu bahan hukum sekunder yaitu bahan yang bersumber langsung dari kepustakaan doktrin maupun referensi ilmiah yang relevan dengan penelitian atau bahan hukum yang memberikan penjelasan mengenai bahan hukum primer dan isinya tidak mengikat, seperti: hasil penelitian hukum dan artikel hukum. $^{7}$

\section{PEMBAHASAN}

Penerapan Ketentuan Diversi Terhadap Perkara Tindak Pidana yang Dilakukan oleh Anak di Pengadilan Negeri Purwokerto.

Proses peradilan anak diharapkan tidak membuat stigma yang negatif terhadap pelaku anak. Hal ini terkait dengan teori tujuan pemidanaan yang mana ada beberapa teori pemidanaan yang terkait dengan diversi. Menurut Wirdjono Prodjodikoro tujuan pemidanaan adalah untuk memenuhi rasa keadilan. $^{8}$ Dalam hukum pidana, teori pemidanaan dibagi menjadi 3 (tiga) golongan yaitu:

1. Teori absolut (vergeldingstheorien) yang dianut oleh Immanuel Kant berpandangan tujuan pemidanaan sebagai pembalasan terhadap para

Soerjono Sukanto, 2014, Pengantar Penelitian Hukum, Cet. Ke 6, UI Press, Jakarta, hal 14.

Wirdjono Prodjodikoro, 2005, Asas-Asas Hukum Pidana, Cetakan Pertama, Sinar Grafika, Jakarta, hal. 4. pelaku karena melakukan kejahatan yang mengakibatkan kesengsaraan terhadap orang lain atau anggota masyarakat. $^{9}$

2. Teori relatif (doeltheorien) dilandasi tujuan (doel) sebagai berikut: ${ }^{10}$

1) Menjerakan dengan penjatuhan hukuman diharapkan pelaku atau terpidana menjadi jera dan tidak lagi mengulangi perbuatannya dan masyarakat umum dapat mengetahui bahwa jika melakukan perbuatan tersebut akan mendapat hukuman yang serupa.

2) Memperbaiki pribadi terpidana daam perakukan dan pendidikan yang diberikan selama menjalani hukuman, terpidana measa menyesal sehingga ia tidak akan mengulangi perbuatan dan kembali kepada masyarakat sebagai orang yang baik dan berguna.

3. Teori gabungan/modern (vereningingstheorien) yang salah satu penganutnya adalah van Bammelen dan Grotius. Grotius menyatakan bahwa penderitaan memang sesuatu yang sewajarnya ditanggung pelaku kejahatan, namun dalam batasan apa yang layak ditanggung pelaku tersebut, kemanfaatan sosial akan menetapkan berat ringannya derita yang layak dijatuhkan. ${ }^{11} \mathrm{Hal}$ bertolak dari suatu adagium yang berbunyi natura ipsa dictat, ut qui malum fecit, malum ferat yang berarti kodrat mangajarkan bahwa

Juhaja S. Praja, 2011, Teori Hukum dan Aplikasinya, Pustaka Setia, Bandung, hal 89. Ibid.

Eddy O.S. Hiariej, 2014, P rinsip-P rinsip Hukum P idana, Cahaya Atma Pustaka, Yogyakarta, hal. 34. 
siapa yang berbuat kejahatan, maka akan terkena derita. Akan tetapi tidak hanya penderitaan semata sebagai suatu pembalasan tetapi juga ketertiban masyarakat. $^{12}$

Berdasarkan beberapa teori-teori pemidanaan diatas, maka dapat dikatakan bahwa pada dasarnya Diversi mempunyai relevansi dengan tujuan pemidanaan anak, yang mana nampak dari hal-hal sebagai berikut :

a. Diversi sebagai proses pengalihan dari proses yustisial ke proses non yustisial, bertujuan menghindarkan anak dari penerapan hukum pidana yang seringkali menimbulkan pengalaman yang pahit berupa stigmatisasi (cap negatif) berkepanjangan, dehumanisasi (pengasingan dari masyarakat) dan menghindarkan anak dari kemungkinan terjadinya prisionisasi yang menjadi sarana transfer kejahatan terhadap anak.

b. Perampasan kemerdekaan terhadap anak baik dalam bentuk pidana penjara maupun dalam bentuk perampasan yang lain melalaui meknisme peradilan pidana, memberi pengalaman traumatis terhadap anak, sehingga anak terganggu perkembangan dan pertumbuhan jiwanya. Pengalaman pahit bersentuhan dengan dunia peradilan akan menjadi bayang-bayang gelap kehidupan anak yang tiak mudah dilupakan.

c. Adanya Diversi tersebut maka anak terhindar dari penerapan hukum pidana yang dalam banyak teori telah didalilkan sebagai salah satu faktor kriminogen, berarti juga menghindarkan anak dari kemungkinan menjadi jahat kembali (residive), menghindarkan masyarakat dari kemungkinan menjadi korban akibat kejahatan.

d. Adanya Diversi akan memberikan 2 (dua) keuntungan sekaligus terhadap individu anak. Pertama; anak tetap dapat berkomunikasi dengan lingkungannya sehingga tidak perlu beradaptasi sosial pasca terjadinya kejahatan. Kedua; anak terhindar dari dampak negatif prisionisasi yang seringkali merupakan sarana transfer kejahatan. $^{13}$

Berdasarkan data wawancara dengan para responden, yaitu hakim pada Pengadilan Negeri Purwokerto, maka didapat hasil sebagai berikut :

Bapak Kristanto Sahat Hamonangan Siregar, S.H., M.H. menerangkan: ${ }^{14}$

Proses penerapan diversi terhadap perkara anak adalah ketika berkas sudah diterima oleh hakim, maka hakim akan mempelajari berkas, selanjutnya apabila ternyata perkara Penanggulangan Tindak Pidana Narkotika Oleh Anak, UMM Press, Malang, hal. 129.

14 Wawancara dengan Bapak Kristanto Sahat Hamonangan Siregar, S.H., M.H. tanggal 19 Februari 2016. 
yang akan diperiksa memenuhi kriteria untuk dilakukan diversi, maka hakim akan memanggil pihak-pihak yaitu anak yang berhadapan dengan hukum yang didampingi oleh orang tua atau walinya, korban/korban anak yang didampingi oleh orang tua atau walinya, Penasehat Hukum Pembimbing Kemasyarakatan. Hakim akan berusaha menjembatani permasalahan-permasalahan yang ada dengan mengutamakan kepentingan anak dan sifat musyawarah tersebut adalah tertutup bagi umum. Apabila tercapai kesepakatan, maka dibuat surat kesepakatan yang dituangkan dalam Berita Acara Diversi dan laporan kepada Ketua Pengadilan. Selanjutnya Ketua Pengadilan akan mengeluarkan Penetapan Diversi yang berisi kesepakatan dan menghentikan proses perkara pidana tersebut.

Bapak Deni Ikhwan, S.H.,M.H. menerangkan: ${ }^{15}$

Hakim akan memanggil pihak-pihak yang terkait dengan pelaksanaan proses diversi, dimana mempertemukan antara pihak anak yang berhadapan dengan hukum yang didampingi oleh orang tua dengan pihak korban, BAPAS, Penasehat Hukum selanjutnya dilakukan musyawarah di runag mediasi guna mencari titik temu permasalahan yang ada,. Apabila

15 Wawancara dengan Bapak Deni Ikhwan, S.H.,M.H. tanggal 19 Februari 2016. berhasil maka dibuat kesepakatan diversi dan apabila tidak berhasil maka perkara diteruskan sesuai hukum acara yang berlaku.

Bapak I Wayan Yasa, S.H. menjelaskan: ${ }^{16}$

Tindakan yang dilakukan adalah menerapkan diversi sesuai dengan ketentuan dalam UU Nomor 11 Tahun 2012 tentang SPPA, dimana diadakan pertemuan yang bersifat kekeluargaan antara pihak anak yang berhadapan dengan hukum yang didampingi orang tua/walinya, korban, Penasehat Hukum, BAPAS dan pekerja sosial, apabila berhasil maka akan dibuat Berita Acara Kesepakatan Diversi untuk selanjutnya dikeluarkan Penetapan dari Ketua Pengadilan Negeri.

Ibu Dian Anggraini, S.H.,M.H. menjelaskan: ${ }^{17}$

Mempertemukan pihak-pihak, anak yang berhadapan dengan hukum yang didampingi oleh orang tua/walinya, korban, BAPAS, Penasehat Hukum dimana hakim berusaha menjembatani musyawarah agar tercapai kesepakatan sehingga proses persidangan dapat dihentikan.

Ibu Ivonne Tiurma Rismauli, S.H., menjelaskan: ${ }^{18}$

Hakim akan mempertemukan pihakpihak yaitu anak yang berhadapan

16 Wawancara dengan Bapak I Wayan Yasa, S.H., tanggal 19 Februari 2016.

Wawancara dengan lbu Dian Anggraini, S.H.,M.H., tanggal 19 Februari 2016.

18 Wawancara dengan Ibu Ivonne Tiurma Rismauli, S.H., tanggal 19 Februari 2016. 
dengan hukum yang didampingi oleh orang tua/walinya dan Penasehat Hukum, korban dan BAPAS. Musyawarah dilakukan di ruang mediasi, diusahakan suasana musyawarah bersifat kekeluargaan dan tidak memojokkan anak dengan kesalahannya, dimana Hakim bertugas sebagai mediator diantara kedua belah pihak. Apabila terjadi kesepakatan, maka dibuat kesepakatan diversi untuk selanjutnya dilaporkan kepada Ketua Pengadilan untuk dibuat Penetapan Diversi. Jika tidak tercapai kesepakatan, maka prosesnya dilanjutkan dengan tahap acara persidangan selanjutnya yaitu pemeriksaan perkara.

Proses penerapan diversi terhadap perkara anak adalah ketika berkas sudah diterima oleh hakim, maka hakim akan mempelajari berkas, selanjutnya apabila ternyata perkara yang akan diperiksa memenuhi kriteria untuk dilakukan diversi, maka hakim akan memanggil pihak-pihak yaitu anak yang berhadapan dengan hukum yang didampingi oleh orang tua atau walinya, korban/korban anak yang didampingi oleh orang tua atau walinya, Penasehat Hukum Pembimbing Kemasyarakatan. Hakim akan berusaha menjembatani permasalahan-permasalahan yang ada dengan mengutamakan kepentingan anak dan sifat musyawarah tersebut adalah tertutup bagi umum. Apabila tercapai kesepakatan, maka dibuat surat kesepakatan yang dituangkan dalam Berita Acara Diversi dan laporan kepada Ketua Pengadilan. Selanjutnya Ketua Pengadilan akan mengeluarkan Penetapan Diversi yang berisi kesepakatan dan menghentikan proses perkara pidana tersebut. berdasarkan Pasal 6 ayat (3) Peraturan Pemerintah Republik Indonesia Nomor 65 Tahun 2015 Tentang Pedoman Pelaksanaan Diversi Dan Penanganan Anak Yang Belum Berumur 12 (Dua Belas) Tahun.

2. Pertimbangan Hakim dalam Penerapan ketentuan Diversi terhadap Perkara Tindak Pidana yang Dilakukan oleh Anak di Pengadilan Negeri Purwokerto.

Salah satu terobosan penting yang ada dalam Undang-Undang Nomor 11 Tahun 2012 tentang Sistem Peradilan Pidana Anak adalah adanya upaya diversi yang merupakan suatu perwujudan dari pemikiran progresif yang bertujuan untuk memperoleh keadilan restoratif. ${ }^{19} \mathrm{Hal}$ ini sebagaimana dikemukakan oleh Hosiana M. Sidabalok sebagai berikut::

Langkah penyelesaian tindak pidana anak yang dianggap tepat oleh sebagian besar pakar hukum pidana dan psikologi perkembangan serta pakar-akar ilmu "tingkah laku", adalah menciptakan ketentuan

Riya Novita, 2014, Penerapan Ketentuan Pidana Undang-Undang Perlindungan Anak Terhadap Pelaku Anak Yang Melakukan Tindak Pidana Kesusilaan Dengan Korban Anak (Kajian di Wilayah Hukum Pengadilan Negeri Banyumas, Pengadilan Negeri Purwokerto, Pengadilan Negeri Purbalingga, Tesis, Fakultas Hukum, Universitas Jenderal Soedirman, Purwokerto. (tidak dipublikasikan), hal. 150. Ibid., hal. 151. 
hukum yang memungkinkan penyelesaian anak yang berkonflik dengan hukum secara baik bagi pelaku dan korban, dan membuat nyaman masyarakat. Konsep tersebut dikembangkan hingga muncul kosep keadilan restorative. Keadilan restorative merupakan perkembangan terakhir dari paradigma yang ada di dunia selama ini, yaitu secara berturutturut : dimulai dari retributive justice, dilanjutkan dengan rehabilitative justice, kemudian ada alternative justice, dan akhirnya digantikan oleh restorative justice.

Berdasarkan hasil wawancara dengan Hakim pada Pengadilan Negeri Purwokerto, maka diperoleh data bahwa hakim dalam mempertimbangkan penerapan diversi dalam perkara anak harus melihat dari berbagai aspek dan komprehensif. Hakim yang berkualitas dapat memahami anak secara secara komprehensif, sehingga semua aspek yang dapat mempengaruhi anak pada masa lalu dan masa mendatang selalu diperhitungkan secara matang. ${ }^{21}$ Lebih lanjut Made Sadhi Astuti berpendapat sebagai berikut :22

Apabila hakim dalam menerapkan hukum pidana tidak mempertimbangkan masa lampau Terdakwa dan tidak memperhatikan masa depan terdakwa, maka akan terjadi putusan yang tidak tepat dan tidak adil. Bahkan dapat berakibat lebih buruk dan fatal apabila putusan tersebut akan dapat merusak masa depan Terdakwa....hakim dalam memutus perkara hendaknya memperhatikan dan mempertimbangkan kausa atau sebab-sebab anak melakukan perbuatan pidana, aspek psikologis dan aspek sosiologis dari anak, agar tercapai putusan yang adil sesuai dengan putusan anak.

Hakim anak yang berkualitas akan mendorong pencapaian misi agung Pengadilan Anak, yaitu untuk : ${ }^{23}$

a) Menjamin pengasuhan hak anak-anak : hak untuk hidup, makanan, berteduh, kasih sayang penuh dari orang tua, pendidikan dan perlindungan dari perbuatan cabul dan kejahatan.

b) Yuisdiksi di atas empat jenis pelanggar yang berusia muda; pelanggar yang melakukan pelanggaran ringan; anakanak yang ditelantarkan oleh orang tua atau walinya; dan mereka yang bergantung dan sedang kekurangan kepedulian.

c) Memenuhi fungsi utama, yaitu menyelenggarakan konsepsi masa kanak-kanak yang modern secara baik, bertindak sebagai pengganti keluarga dan sekolah, mencegah kenakalan, dekriminalisasi terhadap anak-anak, merehebalitasi mereka yang memerlukan kepedulian khusus.

$23 \quad$ Sri Sutatiek, Op.Cit., hal. 54. 
Perkara-perkara anak selama tahun 2014 sampai dengan tahun 2015 selain perkara Nomor 3/Pid.Sus Anak/2015/PN Pwt, tidak ada yang dilaksanakan diversi. Hal ini berdasarkan data-data yang terkumpul dengan petimbanganpertimbangan, ancaman hukumannya yang lebih dari 7 (tujuh) tahun yaitu perkara nomor 1/Pid.Sus-Anak/2014， 2/Pid.SusAnak/2014, 3/Pid.Sus-Anak/2014, 4/Pid.Sus-Anak/2014, 1/Pid.Sus-Anak/2015, 2/Pid.Sus-Anak/2015, 4/Pid.Sus-Anak/2015, 6/Pid.Sus-Anak/2015, 7/Pid.Sus-Anak/2015, 8/Pid.Sus-Anak/2015，9/Pid.Sus-Anak/2015 dan 10/Pid.Sus-Anak/2015. Diversi tidak dilakukan dengan pertimbangan merupakan pengulangan tindak pidana yaitu perkara nomor 5/Pid.Sus-Anak/2015.

Salah satu pendapat dari Ibu Dian Anggraini, berkenaan dengan pertimbangan Hakim dalam menerapkan diversi terhadap anak yang berhadapan dengan hukum menyatakan keberhasilan dalam pelaksanaan diversi pada tingkat pemeriksaan pengadilan, salah satunya adalah kemampuan hakim dalam upaya diversi. Mengenai hal ini Barda Nawawi Arief menjelaskan, kebijakan pengembangan/peningkatan kualitas peradilan tentunya terkait dengan berbagai aspek yang mempengaruhi kualitas peradilan/penegakan hukum. ${ }^{24}$ Berbagai aspek itu dapat mencakup kualitas individual Sumber Daya Manusia (SDM), kualitas institusional/kelembagaan, kualitas

Barda Nawawi Arief, 2001, Masalah Penegakan Hukum dan Kebijakan Penanggulangan Kejahatan, Citra Aditya Bakti, Bandung, hal. 33. mekanisme tata kerja/manajemen, kualitas sarana /prasarana, kualitas substansi hukum/perundang-undangan dan kualitas kondisi lingkungan (kondisi sosial, ekonomi politik, termasuk budaya hukum masyarakat). ${ }^{25}$

\section{PENUTUP}

\section{Simpulan}

1. Pengadilan Negeri Purwokerto telah menerapkan ketentuan diversi dengan proses berawal dari Hakim Anak menerima pelimpahan perkara anak dari penuntut umum anak untuk segera dilakukan pemeriksaan di pengadilan. Pihak pengadilan setelah menerima pelimpahan perkara dari penuntut umum anak, maka segera melakukan pemeriksaan anak nakal tersebut. Hakim dapat menentukan apakah akan dilakukan diversi atau perkara akan diputus pidana. Jika menentukan dilakukan diversi, maka ditentukan program diversi yang tepat bagi anak tersebut, dan perkara dihentikan. Penerapan Divesi di Pengadilan Negeri Purwokerto terlihat dari dikeluarkannya Penetapan Diversi Nomor 3/Pid.Sus Anak/2015/PN Pwt. Bentuk kesepakatan diversi dalam Penetapan Diversi Nomor 3/Pid.Sus Anak/2015/PN Pwt adalah perdamaian tanpa ganti kerugian dan penyerahan kembali kepada orang tua, hal ini sesuai dengan ketentuan Pasal 6 ayat (3) Peraturan Pemerintah Republik Indonesia Nomor 65 Tahun 2015 Tentang Pedoman Pelaksanaan Diversi Dan Penanganan Anak Yang Belum Berumur 12 (Dua Belas) Tahun.

Ibid. 
Adanya Penetapan Diversi Nomor 3/Pid.Sus Anak/2015/PN Pwt, maka terjadi diversi dalam bentuk perdamaian tanpa ganti kerugian dan penyerahan kembali kepada orang tua.

2. Pertimbangan hakim dalam menentukan kesepakatan diversi terhadap perkara tindak pidana yang dilakukan oleh anak di Pengadilan Negeri Purwokerto, lebih menitikberatkan pada kepentingan terbaik anak, yaitu mencapai perdamaian antara korban dan anak, menyelesaikan perkara anak di luar proses peradilan, menghindarkan anak dari perampasan terhadap kemerdekaan, mendorong masyarakat untuk berpartisipasi dan menanamkan rasa tanggung jawab kepada Anak. Hal ini terlihat dari Penetapan Diversi Nomor 3/Pid.Sus Anak/2015/PN Pwt, dimana antara korban/orang tua dan anak/orang tua sudah saling memaafkan, orang tua anak akan mendidik anak agar menjadi anak yang baik dan tidak dilakukan perampasan kemerdekaan tetapi dalam pengawasan BAPAS, sehingga anak berhadapan dengan hukum terhindar dari stigma negatif atas perbuatannya tersebut.

\section{Saran}

1. Sebaiknya Pengadilan Negeri Purwokerto mensosialisasikan ketentuan dalam Undang-Undang Nomor 11 Tahun 2012 tentang Sistem Peradilan Anak mengenai adanya proses Diversi, sehingga masyarakat berpandangan terhadap tindak pidana yang dilakukan anak penanganannya bukan sebagai pembalasan tetapi lebih kepada keadilan restoratif.
2. Sebaiknya dilakukan pelatihan-pelatihan yang berkesinambungan terhadap para Hakim dalam penanganan tindak pidana yang dilakukan oleh anak, khususnya mengenai pelaksanaan diversi.

\section{DAFTAR PUSTAKA}

\section{Buku}

Adi, Kusno, 2009, Diversi Sebagai Upaya Alternatif Penanggulangan Tindak Pidana Narkotika Oleh Anak, UMM Press, Malang.

Arief, Barda Nawawi, 2001, Masalah Penegakan Hukum dan Kebijakan Penanggulangan Kejahatan, Citra Aditya Bakti, Bandung.

Astuti, Made Sadhi, 1997, Pemidanaan Terhadap Anak Sebagai Pelaku Tindak Pidana, IKIP Malang, Malang.

Hiariej, Eddy, O.S., 2014, P rinsip-P rinsip Hukum Pidana, Cahaya Atma Pustaka, Yogyakarta.

Koentjoroningrat, 1986, Metode-Metode Penelitian Masyarakat, Gramedia, Jakarta.

Nawawi, Hadari, 1995, Metode Peneltian Bidang Sosial, Percetakan Universitas Gajah Mada, Yogyakarta

Novita, Riya, 2014, Penerapan Ketentuan Pidana Undang-Undang Perlindungan Anak Terhadap Pelaku Anak Yang Melakukan Tindak Pidana Kesusilaan Dengan Korban Anak (Kajian di Wilayah Hukum Pengadilan Negeri Banyumas, Pengadilan Negeri Purwokerto, Pengadilan Negeri Purbalingga, Tesis, Fakultas Hukum, Universitas Jenderal Soedirman, Purwokerto. (tidak dipublikasikan).

Praja, Juhaja S., 2011, Teori Hukum dan Aplikasinya, Pustaka Setia, Bandung.

Prodjodikoro, Wirdjono, 2005, Asas-Asas Hukum Pidana, Cetakan Pertama, Sinar Grafika, Jakarta.

Soemitro, Ronny Hanitijo, 1998, Metodologi Penelitian Hukum Dan J urimetri, Ghalia Indonesia, Jakarta.

Sugiyono, 2008, Memahami Penelitian Kualitatif, Alfabeta, Bandung.

Sukanto, Soerjono, 2014, Pengantar Penelitian Hukum, Cet. Ke 6, UI Press, Jakarta.

Sutatiek, Sri, 2007, Putusan Pengadilan Anak sebagai Manifestasi Perlindungan dan Kesejahteraan Anak di Indonesia, 
P a g e | 619

Desertasi, Fakutas Hukum Universitas

Brawijaya, Malang.

Internet

http://192.168.88.100:81/cts3 pn/index/index.ph p, diakses pada tanggal 23 November 2015, pukul $16.18 \mathrm{Wib}$. 